\title{
Communication
}

[Comunicação]

\section{Copper toxicosis in sheep fed dairy cattle ration in São Paulo, Brazil}

\author{
[Intoxicação por cobre em ovinos na região de Franca - SP alimentados com ração de bovinos de leite] \\ M.B. Castro $^{1}$, L.A.L. Chardulo ${ }^{2}$, M.P.J. Szabo ${ }^{3 *}$ \\ ${ }^{1}$ Universidade Brasília - Brasília, DF \\ ${ }^{2}$-Faculdade de Medicina Veterinária e Zootecnia - UNESP - Botucatu, SP \\ ${ }^{3}$ Universidade Federal de Uberlândia \\ Av. Pará, 1720/Campus Umuarama-Bloco 2T \\ 38400-902 - Uberlândia, MG
}

Copper $(\mathrm{Cu})$ is an essential element required by ruminants and both excess and deficiency can cause severe illness. Chronic primary copper toxicosis is a common disease in southern Brazil, caused by the ingestion of concentrated food with high levels of cooper, by the use of mineral supplements for cattle, or by the ingestion of contaminated pastures (Riet Correa et al., 1989; Ribeiro et al., 1995; Mendez et al., 1998).

The disease was reported also in the northeastern region (Riet Correa et al., 2003), and in the states of Mato Grosso do Sul (Rosa e Gomes, 1982) and São Paulo. In the latter the disease occurred in ewes after the administration of rabbit ration and cattle mineral supplement (Maiorka et al., 1998).

Sheep's liver has a peculiar avidity for copper and limited rate to excrete the element (Kelly, 1993) and is thus the species most prone to copper poisoning. In this species the chronic toxicosis is the most common form and occurs due to the sub clinic accumulation of copper in the liver for several weeks or months before its release to the blood circulation (Pereira and Rivero, 1993; Méndez, 1998). Mechanisms involved in the massive release of cooper from the liver are still not clear, but factors that cause stress such as diet changes, lactation and transport can precipitate such release (Radostits et al., 2000).
Chronic copper poisoning in sheep occurs as a result of the presence of three factors acting alone or in concert: excessive copper intake; low intake of molybdenum; and as a consequence of liver damage caused by hepatotoxins like pyrrolizidine alkaloids (Radostits et al., 2000). Ilha et al. (2001) demonstrated in Southern Brazil high levels of $\mathrm{Cu}$ in the liver and kidney samples of sheep with spontaneous Senecio brasiliensis poisoning. The animals showed hemolytic anemia that could be attributed to copper toxicosis. According to Riet-Correa et al. (1989) sheep in feed lot fed with concentrate ration with $\mathrm{Cu}$ levels of $15-20 \mathrm{mg} / \mathrm{kg}$ can develop the toxicosis.

In the municipality of Franca, São Paulo, a group of 20 adult, mixed breed sheep kept in feed lot was being fed with coast cross hay and a dairy cattle pelletized concentrate. Approximately, three months after receiving this ration six animals became anorectic and depressed and displayed severe jaundice, hemolitic anemia and dark brown urine due to hemoglobinuria. All animals presenting clinic signs died. By that time it was observed that the ration concentrate being used was for dairy cattle and presented, according to the manufacturer, $20 \mathrm{mg} / \mathrm{kg}$ of copper.

Necropsy of the affected sheep was performed. All animals showed deep jaundice (Fig. 1), with 
livers presenting a yellow to orange color (Fig. 2) and noticeable acinar pattern. The kidneys were dark brown tending to black. Histopathologic analysis of the liver revealed multifocal periacinar necrosis and severe bile retention. The kidneys presented hemoglobinuric nephrosis with the formation of hyaline casts and

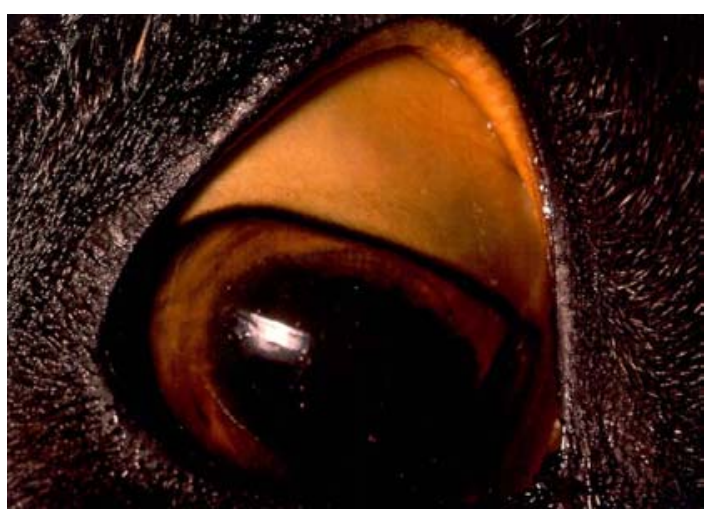

Figure 1. Severe icterus in ocular mucosae in sheep.

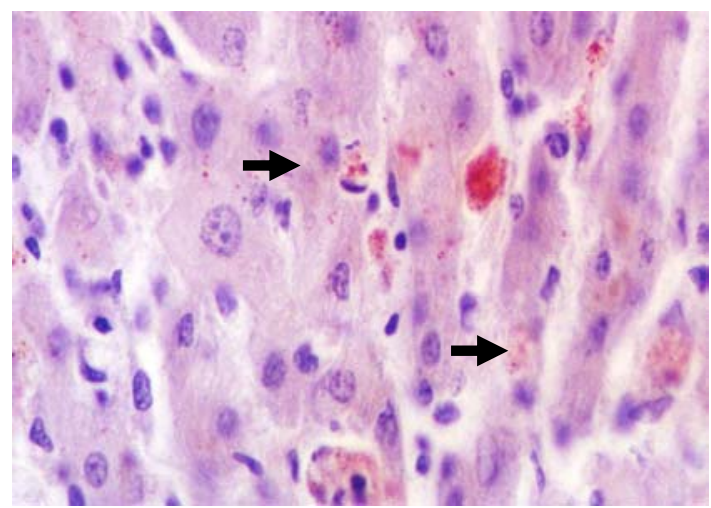

Figure 3. Hepatocytes with cooper deposits (arrow) in sheep; liver - (rhodamine - obj. 40x)

Atomic absorption spectophotometry (AA6800, Shimadzu) showed moderately increased copper levels in the liver, kidney and serum samples of two sheep and too high copper levels for sheep in the sample from the dairy cattle concentrate given to the sheep (Table 1).

Animals from this report were being mistakenly fed with cattle concentrated ration with levels of copper too high for sheep. Moreover it was also intense glomerular edema. Sections of the liver were submitted to the rhodamine staining and accumulated copper was demonstrated in the cytoplasm of hepatocytes and macrophages as fine to coarse brown reddish granules (Fig. 3 and 4).

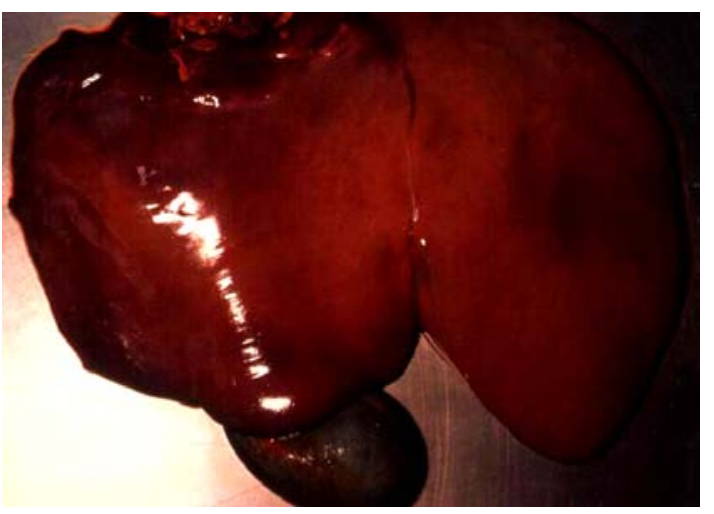

Figure 2. Hepatomegaly and jaundice in sheep.

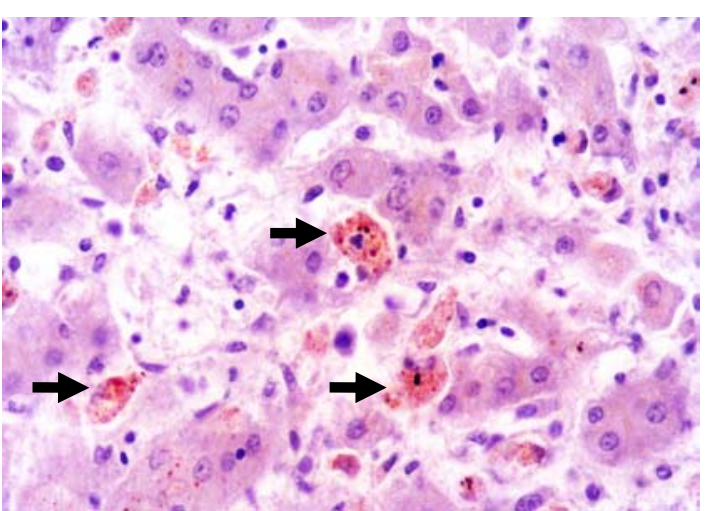

Figure 4. Copper-laden macrophages (arrow) in sheep; liver - (rhodamine - obj. 40x)

determined that this concentrate had higher copper levels than those described in the package of the product $(20 \mathrm{mg} / \mathrm{kg})$. In spite of the only moderately increased level of copper in serum, liver and kidney samples, the animals showed characteristic clinical signs and typical pathologic findings of copper poisoning. Copperladen macrophages and copper deposits in hepatocytes had a heavy accumulation of brownish pigment under rhodamine staining. 
Table 1. Copper $(\mathrm{Cu})$ levels in the dry matter of samples of poisoned sheep and dairy feed

\begin{tabular}{ccc}
\hline Source & Sample & $\mathrm{Cu}(\mathrm{ppm})$ \\
\hline Sheep 1 & serum & 315 \\
Sheep 2 & serum & 225 \\
Sheep 1 & liver & 390 \\
Sheep 2 & liver & 440 \\
Sheep 1 & kidney & 230 \\
Sheep 2 & kidney & 280 \\
$\begin{array}{c}\text { Dairy cattle } \\
\text { concentrate }\end{array}$ & & 65 \\
\hline
\end{tabular}

Johnson et al. (1991) stated that rhodamine staining procedure is a reliable semiquantitative method to evaluate hepatic copper presence in Bedlington Terrier dogs. These authors observed that only a few laboratories are able to precisely evaluate copper levels in tissues even in developed countries. Ilha et al. (2001) detected hemolytic crisis in sheep from an outbreak of spontaneous Senecio brasiliensis poisoning associated with the massive release into the bloodstream of copper accumulated in the liver. Copper levels in liver and kidney samples in these animals ranged, respectively, from 369 to $854 \mathrm{ppm}$ and from 152 to 679ppm. Copper levels described herein fall within these ranges and thus strengthen the copper poisoning outbreak diagnosis. Even though there is only one report on copper poisoning of sheep in São Paulo State (Maiorka et al., 1998), the poisoning herein reported demonstrates that concern should be given to levels of copper given to sheep.

Some recommendations are important to prevent copper intoxication in sheep, including the use of proper concentrated food for sheep with no more than $10 \mathrm{pp}$ of $\mathrm{Cu}$, avoidance of copper supplementation in sheep fed with concentrates, and in grazing sheep the use of mineral supplements with no more than $0.4 \%$ of copper sulfate $(0.1 \%$ of copper $)$. Fast and correct diagnosis of the poisoning is also desirable to lessen further economic losses.

Keywords: sheep, copper toxicosis

\section{RESUMO}

Intoxicação crônica por cobre foi observada em um rebanho de 20 ovinos no município de Franca, São Paulo. Três meses após o início do arraçoamento com feno e ração concentrada peletizada para bovinos de leite, seis animais apresentaram anorexia, icterícia severa e urina marrom escura, e vieram a óbito. Diagnosticou-se doença hemolítica com base em sinais clínicos, alterações macroscópicas observadas na necropsia e observações histológicas. À necropsia todos os ovinos apresentaram icterícia severa, figado amarelado com padrão lobular evidente e rins escuros. As principais alterações histológicas incluíram necrose hepática periacinar e nefrose hemoglobinúrica. Acúmulos de cobre foram demonstrados nos hepatócitos e macrófagos pela coloração rodamina e níveis elevados de cobre mediante espectrofotometria de absorção atômica no soro, fígado e rins de dois ovinos afetados e na ração fornecida.

Palavras-chave: ovino, cobre, intoxicação

\section{REFERENCES}

ILHA, M.R.S.; LORETTI, A.P.; BARROS, S.S. et al. Intoxicação espontânea por Senecio brasiliensis (Asteracea) em ovinos no Rio Grande do Sul. Pesq. Vet. Bras., v.21, p.123-138, 2001

JOHNSON， G.F.; GILBERTSON， S.R.; GOLDFISHER, S. et al. Cytochemical detection of inherited copper toxicosis of Bedlinton Terriers. Vet. Pathol., v.21, p.57-60, 1984.
KELLY, W.G. The liver and biliary system. In: JUBB, K.V.F.; KENNEDY, P.C.; PALMER, N. Pathology of domestic animals. London: Academic, 1993. p.319-406.

MAIORKA, P.C.; MASSOCO, C.O.; ALMEIDA, S.D. et al. Copper toxicosis in sheep: a case report. Vet. Hum. Toxicol., v.40, p.99-100, 1998.

MÉNDEZ, M.C. Intoxicação crônica por cobre. In: RIET-CORREA, F.; SCHILD, A.L.; 
MÉNDEZ, M.C. (Eds.). Doenças de ruminantes $e$ eqüinos. Pelotas: Ed. Universitária, 1998. p.467-72.

PEREIRA, D.; RIVERO, R. Intoxicação crônica fitógena por cobre. In: RIET-CORREA, F.; MÉNDEZ, M.C.; SCHILD, A.L. (Eds.). Intoxicações por plantas e micotoxicoses em animais domésticos. Pelotas: Ed. Hemisferio Sur, 1993. p.299-307.

RADOSTITS, O.M.; BLOOD, D.C.; GAY, C.C. Veterinary medicine. 8.ed. London: Bailliere Tyndall, 2000. p.1442-46.

RIBEIRO, L.A.O; NETO, J.A.S.P.; RODRIGUES, N.C. et al. Intoxicação crônica por cobre em ovinos mantidos em pomar de macieiras. Pesq. Vet. Bras., v.15, p.15-17, 1995.
RIET-CORREA, F.; OLIVEIRA, J.A.; GIESTA, S. et al. Intoxicação crônica por cobre em ovinos no Rio Grande do Sul. Pesq. Vet. Bras., v.9, p.51-54, 1989.

RIET-CORREA, F.; TABOSA, I.M.; AZEVEDO, E.O. et al. Doenças dos ruminantes e eqüinos no semi-árido da Paraíba. Semi-Árido em Foco, v.1, p.2-86, 2003.

ROSA I.V.; GOMES, R.F. Intoxicação crônica por cobre. EMBRAPA/CNPGC, 1982. Comunicado técnico n.14 p.1-3. 